\title{
Article \\ Spanish Poplar Biomass as a Precursor for Nanocellulose Extraction
}

\author{
Sherif Mehanny ${ }^{1}$, Ehab E. Abu-El Magd ${ }^{2}\left(\mathbb{D}\right.$, Simona Sorbara ${ }^{3}$, Jorge Navarro ${ }^{4}\left(\mathbb{D}\right.$ and Rodrigo Gil-San-Millan ${ }^{4, *} \mathbb{( D}$ \\ 1 Mechanical Design \& Production, Faculty of Engineering, Cairo University, Cairo 12613, Egypt; \\ smehanny@cu.edu.eg \\ 2 National Research Center, Cellulose \& Paper Department, Cairo 12622, Egypt; ehab_oracle@yahoo.com \\ 3 Department of Chemistry, Materials \& Chemical Engineering, Politecnico di Milano, 32, 20133 Milano, Italy; \\ simona.sorbara@polimi.it \\ 4 Department of Inorganic Chemistry, University of Granada, Av. Fuentenueva S/N, 18071 Granada, Spain; \\ jarn@ugr.es \\ * Correspondence: rodri.gil.rg@gmail.com; Tel.: +34-6589-7398-6
}

Citation: Mehanny, S.; Magd, E.E.A.-E.; Sorbara, S.; Navarro, J.; Gil-San-Millan, R. Spanish Poplar Biomass as a Precursor for Nanocellulose Extraction. Appl. Sci. 2021, 11, 6863. https://doi.org/ 10.3390/app11156863

Academic Editor:

Amirhesam Amerinatanzi

Received: 1 June 2021

Accepted: 23 July 2021

Published: 26 July 2021

Publisher's Note: MDPI stays neutral with regard to jurisdictional claims in published maps and institutional affiliations.

Copyright: (C) 2021 by the authors. Licensee MDPI, Basel, Switzerland. This article is an open access article distributed under the terms and conditions of the Creative Commons Attribution (CC BY) license (https:// creativecommons.org/licenses/by/ $4.0 /)$.

\begin{abstract}
The effect of acidic hydrolysis duration on nanocellulose size, morphology, and proper ties was investigated, which opens up a whole new horizon of versatility in poplar applications. This study aimed to examine Spanish poplar wastes as raw material to extract crystalline nanocellulose (CNC), which substantiates the importance of poplar wastes. Wastes were pulped using $1 \mathrm{~L}$ of $10 \% \mathrm{NaOH}$ (wt./wt.) solution, and bleached several times by $\mathrm{NaClO}_{2}$; afterwards, white wastes were subjected to acidic hydrolysis by $60 \% \mathrm{H}_{2} \mathrm{SO}_{4}$ for either 5, 10, or $15 \mathrm{~min}$. Microcrystalline cellulose (MCC) underwent a similar hydrolysis protocol as poplar as control. TEM, IR, and XRD characterization techniques were performed. Poplar based nanocellulose sized $219 \mathrm{~nm}$ length and $69 \mathrm{~nm}$ width after $15 \mathrm{~min}$ acidic hydrolysis. MCC yielded $122 \mathrm{~nm}$ length and $12 \mathrm{~nm}$ width crystals after 10 min acidic hydrolysis. Hydrolysis resulted in a drastic change and intense peaks at 3500 and $2900 \mathrm{~cm}^{-1}$ for nanocellulose. Although pre-hydrolysis fiber treatment was not influencial on the crystallinity of poplar, acidic hydrolysis remarkably raised the crystallinity index (CI) by 7-8\%. The more hydrolysis duration was prolonged, the size of the resulting crystal (whisker) decreased, and the aspect ratio increased. Hydrolysis was more impactful on MCC than poplar. However, for future work, it seems that longer duration of pulping and bleaching could have significantly removed unwanted components (hemicellulose and lignin), showcased in IR and XRD, and hence smoothened the following hydrolysis.
\end{abstract}

Keywords: bioresources; biomaterials; nanocellulose; residues; valorization; acidic hydrolysis

\section{Introduction}

During the recent decades, increasing environmental awareness incited many governments, institutions, and firms to reduce fossil fuel consumption. Carbon footprint and resource non-renewability are amid the fundamental reasons to lessen dependence on petroleum resources. In the same context, lignocellulosic biomass emerged as a reliable alternative for petroleum based plastics [1]. Lignocellulosic biomass is estimated to be the most widely spread biopolymer on earth. Global annual production of this biopolymer is roughly calculated to be $1.3 \times 10^{10}$ metric tons [2]. Lignocellulosic biomass encompasses: (1) agriculture wastes (palm residues, empty fruit bunch, straw, bagasse, corncob, and stover), (2) forest wastes (branches, unwanted stems, and withered leaves), (3) food wastes, and (4) industrial wastes (waste paper, and demolished wood) [3]. Ample of lignocellulosic residues and their capacity to act as a "carbon sink" promoted their use in more than 200 applications, comprising construction materials, moderate strength composites, adhesives, packaging, coatings, dental fillings, implants, scaffolding, and drug delivery [2,4,5]. However, mechanical reinforcement performed by lignocellulosic fibers is the major application 
proven to develop many products [6,7]. Energy generation can be a direct application to lignocellulose either through bioethanol production [8] or combustion of biomass through gas turbine [9]. Lignocelluloseic biomass has advantage over other types of biomass (for instance, poultry wastes and algae) in the terrestrial abundance in large quantities and low content of ash $[10,11]$. Lignocellulosic biomass consists of cellulose chains (monomer is glucose) winded with hemicellulose threads, and all wrapped in phenolic aromatic lignin medium [12]; the chemical composition of each of these constituents varies from one plant to another. However, cellulose varies from 35 to $45 \%$, hemicellulose varies from 22 to $30 \%$, and lignin from 12 to $20 \%$ [13]. Poplar (poplus sp.) is considered a rich source of lignocellulosic biomass. Around the globe, indigenous and planted poplar tree area surpassed 80-90 million ha $[14,15]$. In addition to rapid growth, the poplar cultivation technique can be tailored to serve diverse applications. For instance, construction wood, paper pulp, and biofuel are promising applications to poplar tree; just like other biomass including algae and poultry waste $[10,16]$, poplar showcased promising results to produce fuel $[17,18]$. In addition, poplar ability to grow on waste water promoted its phytoremediation capacity [19]. In Spain, poplar area surpassed 144,000 ha, with 17,000 ha in the Andalusian region only. High planting density in Andalusia (1320 tree/ha) reduces the quality of harvested material, with 13 tons/ha dry waste, which makes it more sensical to develop ways to valorize extracted waste biomass $[19,20]$. Amid poplar wastes valorization methodologies, we can mention the development of nanocellulose extraction protocols from poplar. Nanocellulose is a magical particle which has received ever increasing interest during the last two decades. Nanocellulose mechanical properties are a non-negligible asset, the tensile strength of nanocellulose exceeds $10 \mathrm{GPa}$ (10 times of steel), and its tensile modulus averages to $130 \mathrm{GPa}$ despite its low density $\left(1.5-1.6 \mathrm{gm} . \mathrm{cm}^{3}\right)$ [21]. Low thermal expansivity and capacity to form translucent films (particle smaller than light wavelength), in addition to vapor and $\mathrm{O}_{2}$ barrier properties and, most importantly, biocompatibility (or biodegradability) enabled nanocellulose to become a versatile material in a multitude of applications [22-24]. Polymeric composite reinforcement and paper (board) strengthening are direct applications to high mechanical properties [25,26]. Barrier properties, in addition to mechanical properties and biodegradability, make nanocellulose a perfect match for packaging solutions [27]. Moreover, nanocellulose has a well-proven and promising role in the developing construction, energy, and electronics industries [28].

Nanocellulose can be extracted through one of many routes. The first one is mechanical extraction, where mechanical work is exerted through disc grinder, ball milling, sonicator, or homogenizer to disintegrate the cellulosic hierarchy, yielding cellulose nanofibrils $(\mathrm{CNF})$, which exhibit a very high aspect ratio and moderate crystallinity [29]; long fibrils entanglement yields highly viscous suspensions even at relatively low concentrations (lower than $1 \mathrm{wt} \%$ ) [30]. The second one is biological extraction; bacterial preparation is performed in which bacteria assemble glucose monomers in long cellulose chains, yielding bacterial nanocellulose (BNC), which carries both advantages of high crystallinity and a very high aspect ratio [31]. BNC is an extracellular product of bacterial microorganisms. The most reportedly productive organism is Gluconacetobacter Xylinum. Unlike plant-sourced nanocellulose, which usually requires pretreatment to remove hemicellulose and lignin before hydrolysis, BC is synthesized (constructed) as pure cellulose. BC nanofibers generally size $20-100 \mathrm{~nm}$ in diameter and micrometers in lengths [32]. The third route is utilizing an ionic liquid to extract highly crystalline nanocellulose [33], as the major advantage of ionic liquids is their recyclability. The fourth route is chemical extraction in which an acid (majorly sulphuric acid) attacks amorphous regions of the cellulosic structure leaving $\mathrm{CNC}$, which exhibits a moderate aspect ratio and very high crystallinity [29,34], generally 5-20 $\mathrm{nm} \times 100-500 \mathrm{~nm}$ dimensions and sulfuric acid sourced sulfate group, of negative charge are grafted on $\mathrm{CNC}$, which performs a preventive action against aggregation and flocculation in water suspension due to electrostatic repulsion (-ve charge) between particles. In this article, we will attempt to provide those willing to proceed in the nanocellulose field a preliminary scientific background to build upon in 
their research. The main objective of this study was to investigate nanocellulose extraction, chemically from Andalusian poplar wastes. MCC underwent the same hydrolysis process as a control experiment; we also sought to understand the effect of hydrolysis time on the produced CNC.

\section{Materials and Methods}

\subsection{Materials}

Poplar residues of $2 \%$ moisture content and $0.5-1 \mathrm{~cm}$ size were cordially gifted from the wood lab in University of Granada (Dr. Francisco José Rescalvo Fernández). After mechanical grinding in a lab blender, ground residues were squeezed to remove excess water and dried in oven for $24 \mathrm{~h}$; finally residues were kept in plastic bags until further processing. Microcrystalline cellulose, purchased from Alfa Aeser (A17730), was used as experiment control.

\subsection{Preparation}

Pulping of poplar residues was performed by mixing $100 \mathrm{gm}$ of biomass with $1 \mathrm{~L}$ of $10 \% \mathrm{NaOH}$ (wt./wt.); the mixture was heated up to $120{ }^{\circ} \mathrm{C}$ for $2 \mathrm{~h}$, and then fibers were washed thoroughly and dried in oven. Afterwards, each $10 \mathrm{gm}$ of pulped fibers were subjected to a bleaching process to remove lignin remnants by reaction with sodium chlorite in acidic medium $\left(1.5 \mathrm{gm} \mathrm{NaClO} / 400 \mathrm{~mL} \mathrm{H}_{2} \mathrm{O}+15 \mathrm{~mL}\right.$ acetic acid, all in $100{ }^{\circ} \mathrm{C}$ water bath). Generally, the bleaching process was repeated 3-4 times to approach perfect white fibers. Both bleached poplar residues and lab grade cellulose underwent acidic hydrolysis, by adding $1 \mathrm{gm}$ of cellulose (or bleached poplar) to $20 \mathrm{~mL}$ of $60 \% \mathrm{H}_{2} \mathrm{SO}_{4}$ $(v / v)$ and heated to $40{ }^{\circ} \mathrm{C}$ for 5, 10, and $15 \mathrm{~min}$ with stirring. Acidic hydrolysis reaction was interrupted by quenching in $500 \mathrm{~mL}$ of ice. Subsequently, resulting suspension was centrifuged at $6000 \mathrm{rpm}$ for $15 \mathrm{~min}$. Following that, the supernatant was decanted and replenished by $\mathrm{dI}$ water. The $50-\mathrm{mL}$ tube was shaken and recentrifuged. Eventually the last 2 steps were repeated 1-2 times, simultaneously with adding $5 \%$ w/v $\mathrm{NaHCO}_{3}$ until a $\mathrm{pH}$ approaching 7-8 was obtained. Concentrate was preserved in 10-mL glass vials in the fridge until further characterization. In order to go through this procedure, many attempts were performed in the preliminary phase; however, generally in documented experiments, 2 experimental repetitions were conducted for all samples.

\subsection{Characterization}

Transmission electron microscopy (TEM) was performed using TEM902 Carl Zeiss system (Meditec, Inc., Oberkochen, Germany). Beforehand, samples were prepared in 1:2 water: ethanol, then bath sonicated for $13 \mathrm{~min}$. Ethanol was added to speed up the volatilization of liquid from the grid. Infrared spectroscopy was performed using FTIR spectrometer (TENSOR 27, Bruker Corp.) in the range between 4000 and $400 \mathrm{~cm}^{-1}$, and $2 \mathrm{~cm}^{-1}$ resolution. XRD analysis was performed using Desktop D2 Phaser X-ray diffractometer (Bruker Corp.) with radiation at $30 \mathrm{kV}$ and $10 \mathrm{~mA}$. Diffraction angle varied from $2 \theta=4-40^{\circ}$ with step size of $0.33^{\circ} / \mathrm{s}$. Crystallinity index (CI) was calculated by a formula reported elsewhere [35,36]; CI = (Icryst.-Iam)/Icryst, where Icryst. is the maximum intensity in the diffractogram, most commonly at (2 00$)$ peak, Iam is the intensity of the amorphous valley between $\left(\begin{array}{lll}2 & 0 & 0\end{array}\right)$ and $\left(\begin{array}{lll}1 & 1 & 0\end{array}\right)$, mostly at $2 \theta=18^{\circ}$.

\section{Results and Discussions}

In Figure 1, the TEM morphological depiction of poplar sourced nanocellulose is showcased. As explained in the caption, three types of nanocellulose are depicted. Figure 1B,D,F are zoomed spots of Figure 1A,C,E; hydrolyzed for 5, 10, and 15 min, respectively. Acidic hydrolysis for 5 min yielded splotch-like structure morphology, of minimal portion of whisker shaped parts. Hydrolysis for 10 min yielded more fibril-like shape; a higher aspect ratio is quite clearer in Figure $1 \mathrm{~B}$ than Figure 1A. Hydrolysis for $15 \mathrm{~min}$ yielded a mesh-like structure, more likely to appear like whiskers between nodes. It is obvious that for the 
three hydrolysis durations $(5,10$, and $15 \mathrm{~min})$, as the hydrolysis duration increases, the morphology transforms from splotch to meshed-like whiskers. This observation is valid for figures which are zoomed out (Figure 1A,C,E) and those zoomed in (Figure 1B,D,F). Finer morphology with longer duration can be elucidated by increasing the likelihood of each region to be hydrolyzed, yielding whisker-shaped CNC.
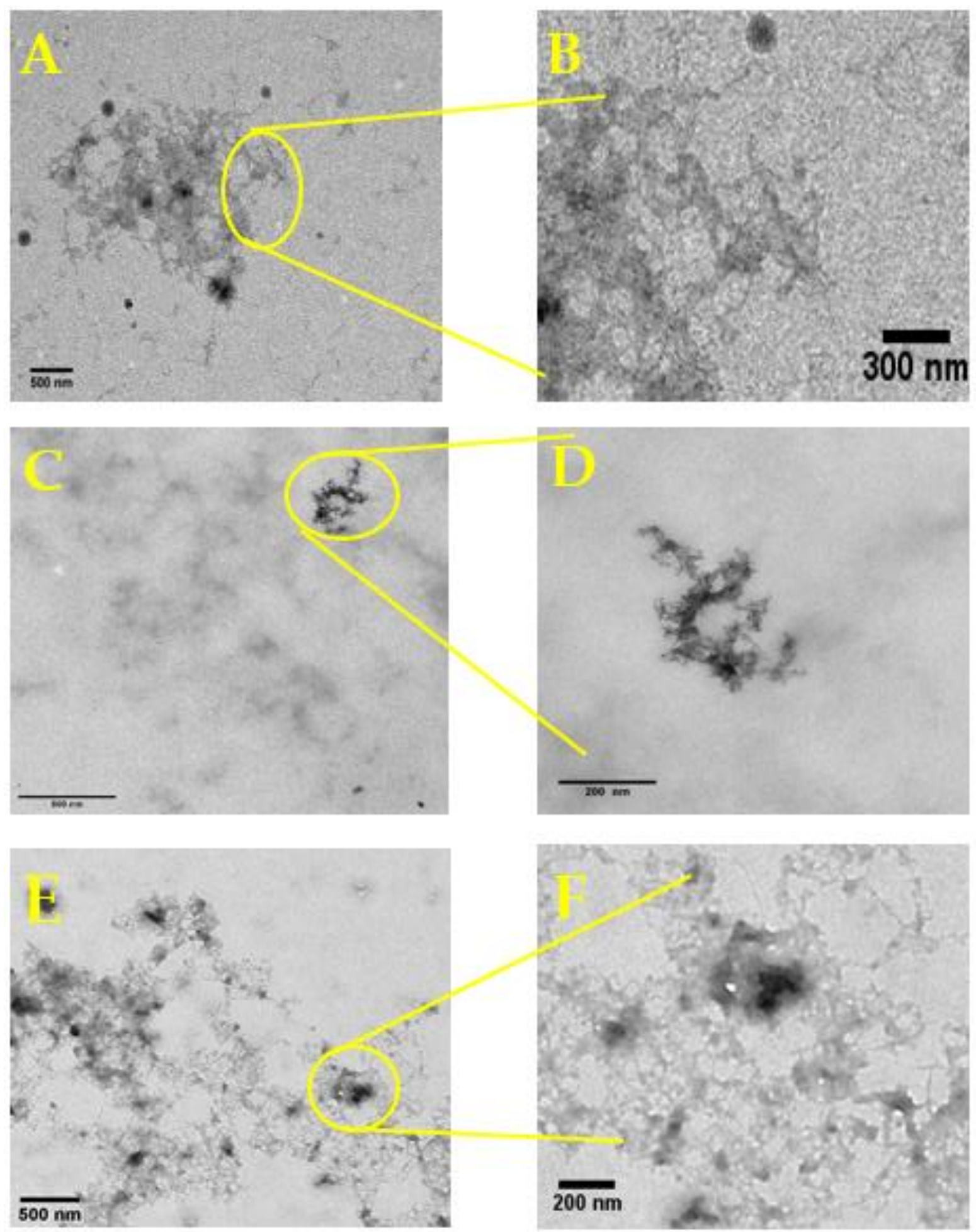

Figure 1. TEM investigation of poplar sourced cellulose nanocrystals (CNC). (A,B) depict CNC after 5 min of hydrolysis; (C,D) depict CNC after $10 \mathrm{~min}$ of hydrolysis, and (E,F) depict CNC after 15 min of hydrolysis. 
The morphology of MCC sourced nanocellulose is exhibited in Figure 2. Results of two hydrolysis durations (5 and $10 \mathrm{~min}$ ) are showcased in Figure 2A,B, and Figure 2C,D, respectively. Hydrolysis for $5 \mathrm{~min}$ resulted in distanced (or dispersed) groups of attached whiskers; the magnified rightwards figure shows nodal connection, and longitudinal attachment between whiskers. The 10-min hydrolysis yielded a uniformly distributed meshed structure of almost uniform whisker diameter in the magnified figure.

To quantitatively compare between poplar and MCC, ImageJ tool was employed to measure the lengths and widths of whiskers (or other particles) from the two sources, which were subjected to different hydrolysis durations (processing time). The values in Table 1 were based on Figure 1A,C,E and Figure 2A,C. The table shows that whiskers originated from MCC are smaller than those from poplar by about $50 \%$ (length), and by $70 \%$ (width). Generally, as the processing time increased, both length and width decreased; however, width was more affected by time than length. Maximum processing time for poplar yielded 68.8-nm width whiskers, with aspect ratio 3.2. MCC yielded 19.9-nm width whiskers, with aspect ratio 10.1. Zoomed depictions (Figure 1B,D,F and Figure 2B,D) after size measurement by ImageJ showed s smaller size than other figures; poplar sourced nanocellulose was of 23-nm width with aspect ratio 5.5 after $15 \mathrm{~min}$, and MCC sourced nanocellulose yielded $10.9 \mathrm{~nm}$ with aspect 7 .
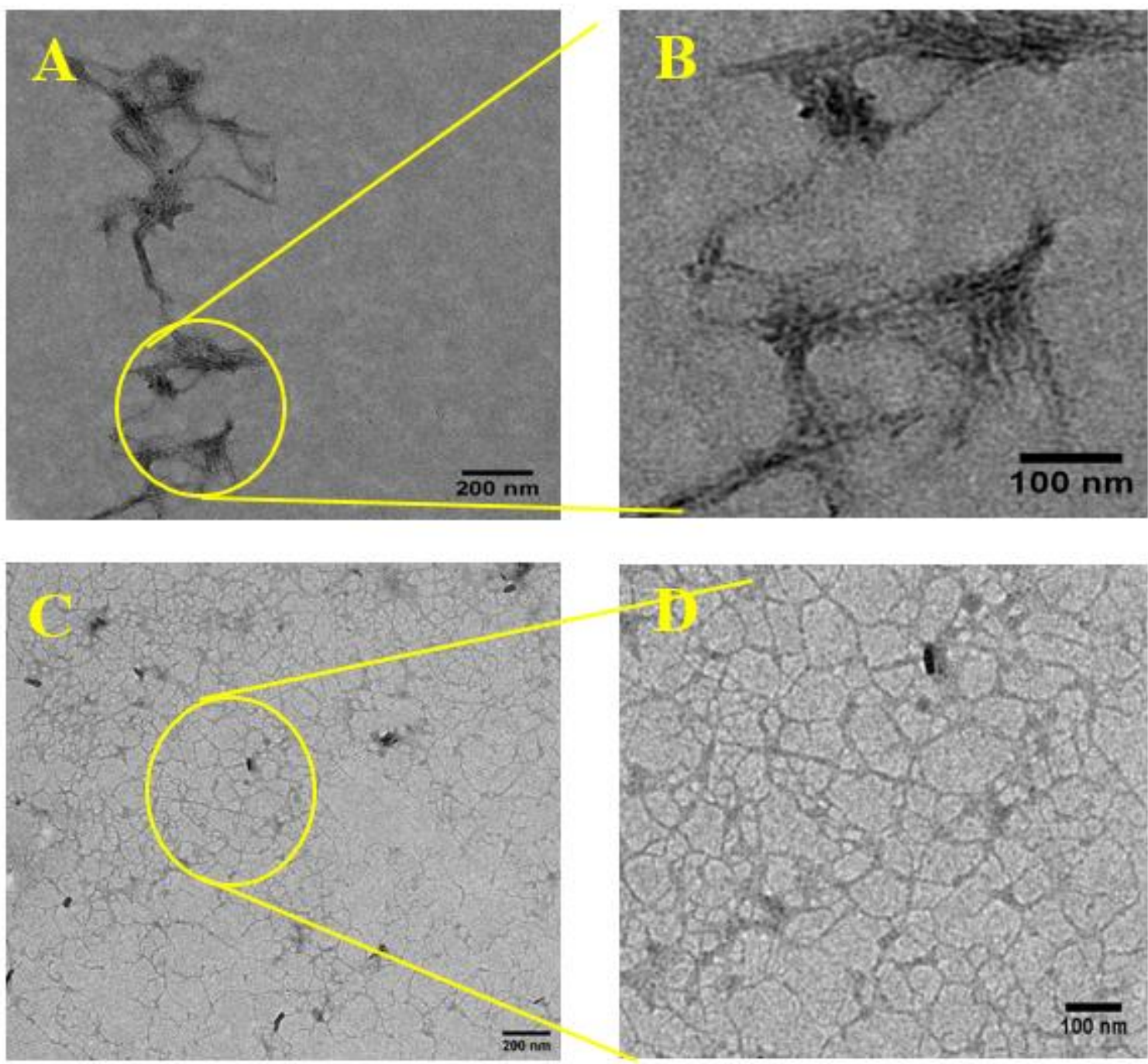

Figure 2. TEM investigation of MCC sourced cellulose nanocrystals (CNC). (A,B) depict CNC after 5 min of hydrolysis; (C,D) depict CNC after 10 min of hydrolysis. 
Table 1. Size distribution (length and width) of cellulose nanocrystals (CNC), sourced from either poplar or microcrystalline cellulose (MCC), measured from TEM photos showcased previously.

\begin{tabular}{|c|c|c|c|c|c|c|c|c|}
\hline \multirow[b]{3}{*}{ Processing time $(\mathrm{min})$} & \multicolumn{4}{|c|}{ Poplar } & \multicolumn{4}{|c|}{ MCC } \\
\hline & \multicolumn{2}{|c|}{ Length } & \multicolumn{2}{|c|}{ Width } & \multicolumn{2}{|c|}{ Length } & \multicolumn{2}{|c|}{ Width } \\
\hline & 5 & 15 & 5 & 15 & 5 & 10 & 5 & 10 \\
\hline Average (nm) & 371.7 & 218.8 & 131.1 & 68.8 & 141.5 & 122 & 39.9 & 19.9 \\
\hline Std. dev. (nm) & 192.1 & 172.1 & 88.8 & 37 & 42 & 34.5 & 12.7 & 5.1 \\
\hline Max. (nm) & 922 & 815 & 402 & 157 & 232 & 208 & 77 & 29 \\
\hline Min. (nm) & 100 & 56 & 23 & 21 & 66 & 52 & 19 & 9 \\
\hline
\end{tabular}

Fourier Transform Infrared (IR) was conducted on all samples (Figure 3). Analysis encompassed untreated poplar fibers, treated fibers, poplar sourced nanocellulose, MCC, and MCC sourced nanocellulose. IR helped in characterizing the chemical structure by recognizing the functional groups present in each investigated sample. IR spectra of cellulose, hemicellulose, and lignin components were studied previously in the literature [37-41]. Typical functional groups and corresponding bands for each component are listed elsewhere [39,40,42].

All characterized samples showed main absorbance regions. The first one was at low range of 700-1800, and the second one at higher range between 2700 and 3500 wave number/cm approximately. Very narrow ranges between 2200 and 2400 wave number/cm were exhibited as well. Specific absorption peaks could be recognized for each particular constituent of the lignocellulose texture (Figure 3).

For the three components of lignocellulosic tissue (cellulose, hemicellulose, and lignin), hydroxyl group stretching vibrations were found between $3000 \mathrm{~cm}^{-1}$ and $3500 \mathrm{~cm}^{-1}$. Peak intensity in hydrolyzed poplar (Figure 3B) was dramatically higher than $n$ non-hydrolyzed poplar (Figure 3A). This can be attributed to the lower diameter of nanocellulose, which implies a larger specific area and therefore a larger number of hydroxyl group [43]. Native poplar in Figure 3A showed a unique peak at $1601 \mathrm{~cm}^{-1}$ (which does not appear in treated fibers) corresponding to $\mathrm{C}=\mathrm{C}$ unsaturated components. At $2890 \mathrm{~cm}^{-1}$, the $\mathrm{H}-\mathrm{C}-\mathrm{H}$ group peak became more intense after hydrolysis (compare Figure $3 \mathrm{~A}, \mathrm{~B})$, probably because of the same reason as for the $\mathrm{OH}$ group.

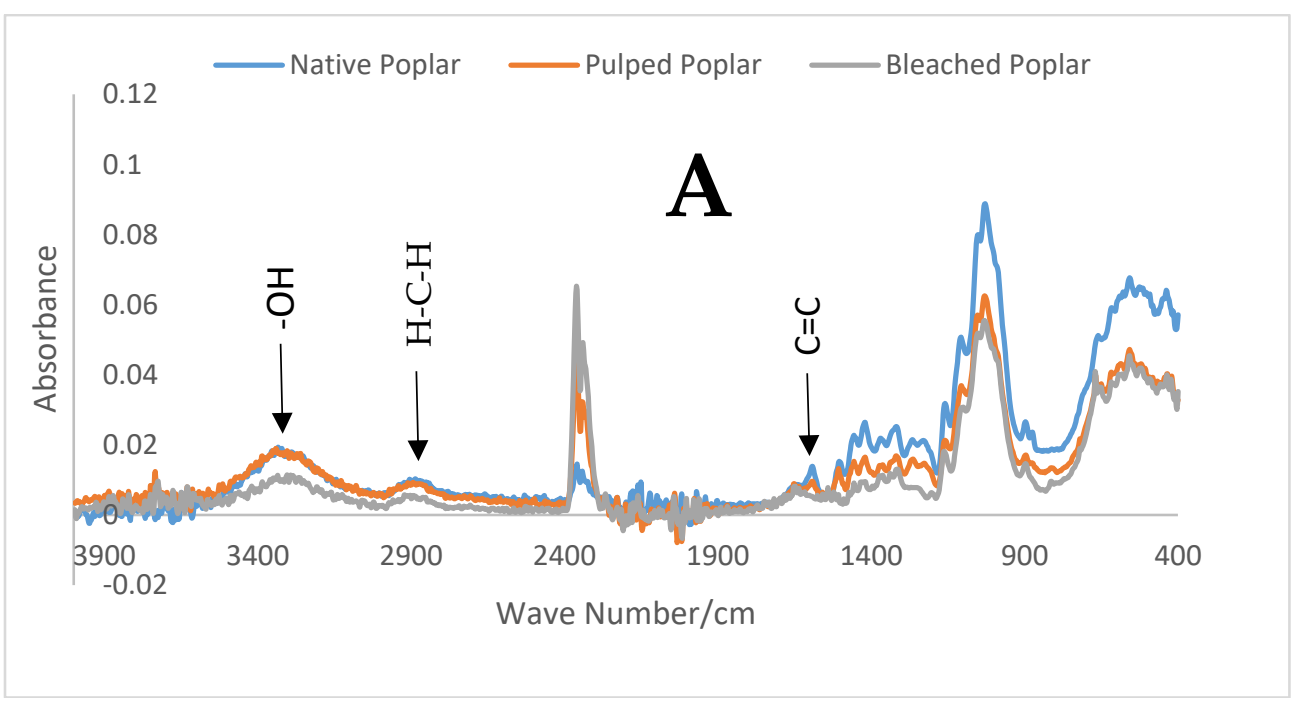

Figure 3. Cont. 


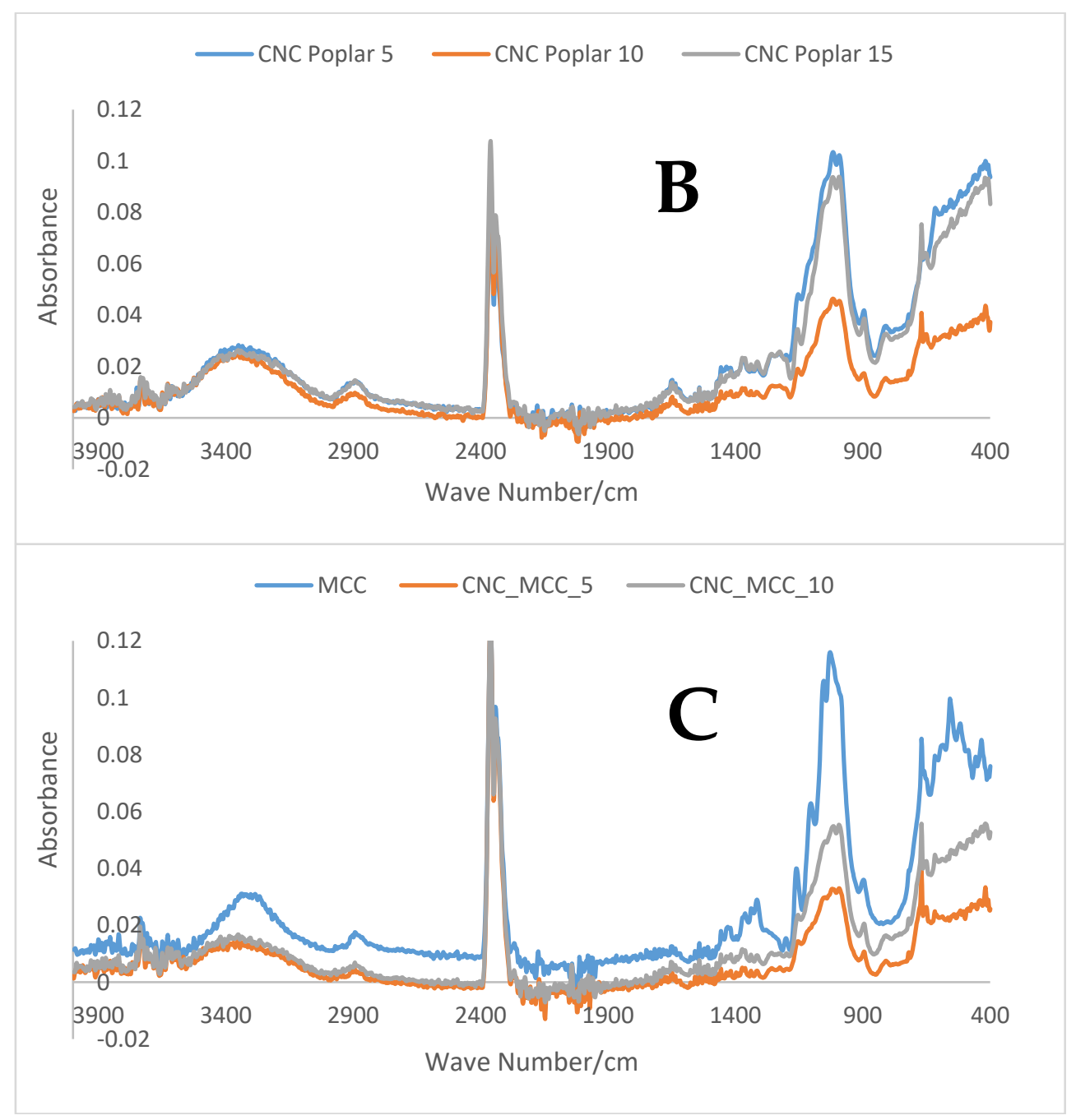

Figure 3. FTIR spectral investigations of (A) Native, pulped, and bleached poplar, (B) Cellulose nanocrystals (CNC) sourced from poplar after 4, 10, and $15 \mathrm{~min}$ of hydrolysis, and (C) microcrystalline cellulose (MCC) and CNC sourced from MCC after 5 and $10 \mathrm{~min}$ of hydrolysis.

Crystallinity was characterized by XRD technique, and the results were showcased in Figure 4. This is as explained in [44]. Cellulose diffractograms showed the following peaks: $2 \theta=12.5^{\circ}$ (for 110 plane), labeled " 1 " in Figure 4, $2 \theta=15.5^{\circ}$ (for 101 plane), labeled "2", $2 \theta=16.5^{\circ}$ (for 101 plane), labeled " 3 ", $2 \theta=19.5^{\circ}$ (for 021 plane), labeled " 4 ", $2 \theta=22.5^{\circ}$ (for 200 plane), labeled " 5 ", $2 \theta=34.5^{\circ}$ (for 040 plane), labeled " 6 ". In this investigation, all types of non-hydrolyzed cellulose (native poplar, pulped poplar, bleached poplar, and MCC), exhibited two peaks, a low one at $2 \theta=15.5^{\circ}$ (overlapping with $2 \theta=16.5^{\circ}$ ) and a higher one at $2 \theta=22.5^{\circ}$; additionally, MCC showed small peaks at $2 \theta=19.5$ and $2 \theta=34.5^{\circ}$. All hydrolyzed samples, called cellulose nanocrystals (CNC), depicted the similar peak location as non hydrolyzed samples. However, contrary to non-hydrolyzed samples, peak 1 was quite clear, and peak 4 was significantly higher than peak 5 , forming doublet shaped peak, the pattern which is documented elsewhere for nanocellulose [35,45,46]. Doublet peaks corroborate the existence of two cellulose polymorphs, namely cellulose I (represented by I22.5) and cellulose II (represented by I19.5) [35]. The higher peak at $2 \theta=19.5^{\circ}$ of hydrolyzed cellulose (nanocellulose) in our work suggests that the content of cellulose II was higher than that of cellulose I. 


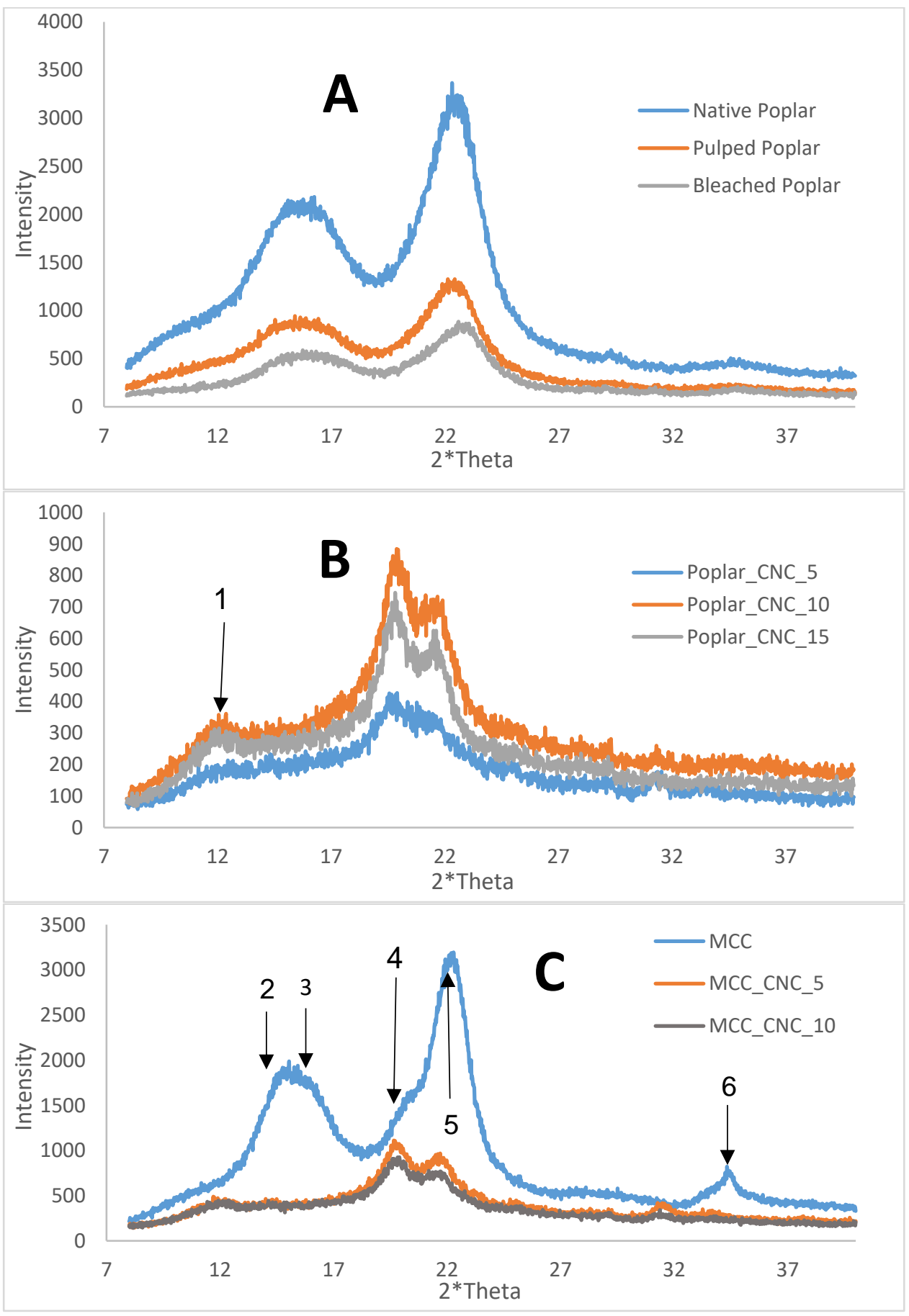

Figure 4. XRD characterization of (A) Native, pulped, and bleached poplar, (B) Cellulose nanocrystals (CNC) sourced from poplar after 4, 10, and 15 min of hydrolysis, and (C) microcrystalline cellulose (MCC) and CNC sourced from MCC after 5 and $10 \mathrm{~min}$ of hydrolysis.

In Table 2, the efforts to extract poplar nanocellulose are summarized, which were published by incidence during the last year. Conventional poplar residues were mainly used; however, two attempts were performed on poplar catkin fibers and APMP. Cellulose purification was carried out commencing with bleaching (using $\mathrm{NaClO}_{2}$ ) for lignin removal, then pulping using alkali to remove hemicellulose. In some cases, repeated cycles of bleaching and pulping combined were carried out [47]. Only one article showcased steam explosion to remove hemicellulose and to activate lignocellulosic texture [48]. Nanocellulose extraction was performed by mechanical means to yield nanofibrils or 
chemical means to extract nanocrystals, or a combination of both means. Mechanical extraction comprised probe sonication and disc grinding; chemical extraction was either acidic reaction $\left(\mathrm{H}_{2} \mathrm{SO}_{4}\right)$ or enzymatic hydrolysis applying cellulase enzyme. Disc grinding yielded smaller sized particles than probe sonication; cellulose nanofibrils from grinding showed 20-30 nm [47] and $18.5 \mathrm{~nm}$ [49], whereas probe sonication yielded 15-70 nm [50] and 20-90 nm [51]. Acidic hydrolysis resulted in smaller sized particles than mechanical extraction, with $11.4 \mathrm{~nm}$ diameter [50] and $69 \mathrm{~nm}$ (this study). Only enzymolysis yielded extremely large size particles of $300 \mathrm{~nm}$ [48], which does not promote this method as a poplar nanocellulose extraction technique. As expected, $\mathrm{CNC}$ resulting from acidic hydrolysis showed higher crystallinity than CNF. The interpretation is that acidic hydrolysis targets amorphous regions, boosting up the percentage of the crystalline part. Comparing this study to the literature, especially [49], we can find that more effort should have been exerted in pulping and bleaching. In [49], there were five bleaching processes followed by pulping, then bleaching, and finally pulping again. This allows to interpret the smaller size of the resulting CNC and its higher crystallinity compared to this study.

Table 2. Literature published in poplar based nanocellulose; cellulose purification, nanocellulose extraction, and resultant properties are listed.

\begin{tabular}{|c|c|c|c|c|c|c|}
\hline & \multicolumn{2}{|c|}{ Cellulose Purification } & \multirow{2}{*}{$\begin{array}{l}\text { Nanocellulose } \\
\text { Extraction }\end{array}$} & \multirow{2}{*}{ Size } & \multirow{2}{*}{ IR and Crystallinity } & \\
\hline & Step 1 & Step 2 & & & & \\
\hline poplar & $\begin{array}{c}\mathrm{NaClO}_{2} \text { for } 1 \mathrm{~h} \\
\text { (6 times) } \\
\text { then } \\
2 \mathrm{wt} \% \mathrm{KOH} \\
90{ }^{\circ} \mathrm{C} \text { for } 2 \mathrm{~h}\end{array}$ & $\begin{array}{c}\mathrm{NaClO}_{2} \text { for } 2 \mathrm{~h} \\
\text { then } \\
5 \mathrm{wt} \% \mathrm{KOH} \\
90^{\circ} \mathrm{C} \text { for } 2 \mathrm{~h}\end{array}$ & $\begin{array}{c}0.3 \mathrm{wt} \% \text { disc } \\
\text { grinder } 1500 \mathrm{r} / \mathrm{min} \\
\text { Then } \\
\text { high-pressure } \\
\text { homogenizer } \\
700 \text { bar then } 100 \\
\text { bar } 30 \mathrm{~min}\end{array}$ & $\begin{array}{c}\text { CNF } \\
20-30 \mathrm{~nm}\end{array}$ & $\begin{array}{c}\text { FTIR } \\
\text {-Lignin removal } \\
\text { Crystallinity } \\
\text { Native pop. } 55 \% \\
\text { CNC pop. } 60 \%\end{array}$ & [47] \\
\hline poplar & $\begin{array}{c}\text { Steam } \\
\text { explosion } \\
2 \mathrm{MPa} 180 \mathrm{~s}\end{array}$ & $\begin{array}{c}\mathrm{NaClO}_{2} \\
(9.7 \mathrm{~g} / \mathrm{L}) \text { for } 1 \mathrm{~h} \\
\text { at } 75^{\circ} \mathrm{C}\end{array}$ & $\begin{array}{l}\text { Enzymolysis } \\
\text { Cellulase (diff time, } \\
\text { temp, and conc) } \\
\text { Then } \\
\text { Probe sonicator } \\
20 \text { min, } 200 \mathrm{~W}\end{array}$ & $\begin{array}{l}\text { CNC } \\
310 \mathrm{~nm}\end{array}$ & $\begin{array}{c}\text { FTIR } \\
\text {-Lignin removal } \\
\text { Crystallinity } \\
\text { Native pop. } 45 \% \\
\text { CNC pop. } 62 \%\end{array}$ & [48] \\
\hline poplar & $\begin{array}{l}\mathrm{NaClO}_{2} 70^{\circ} \mathrm{C} \\
\text { for } 1 \mathrm{~h} \\
\text { ( } 5 \text { times) } \\
\text { Then } \\
5 \mathrm{wt} \% \mathrm{NaOH} \\
\text { at } 90^{\circ} \mathrm{C} \text { for } 2 \mathrm{~h} \\
\end{array}$ & $\begin{array}{c}\mathrm{NaClO}_{2} 70^{\circ} \mathrm{C} \\
\text { for } 1 \mathrm{~h} \\
\text { Then } \\
5 \mathrm{wt} \% \mathrm{NaOH} \\
\text { at } 90{ }^{\circ} \mathrm{C} \text { for } 2 \mathrm{~h}\end{array}$ & $\begin{array}{c}64 \mathrm{wt} \% \mathrm{H}_{2} \mathrm{SO}_{4} \\
45^{\circ} \mathrm{C} \text { for } 30 \mathrm{~min} \\
(\mathrm{OR}) \\
1 \% \text { wt disk grinder } \\
1500 \mathrm{rpm} \text { for } \\
5 \text { times }\end{array}$ & $\begin{array}{c}\mathrm{CNC} \\
11.4 / 153.2 \mathrm{~nm} \\
\mathrm{CNF} \\
18.5 \mathrm{~nm}\end{array}$ & $\begin{array}{c}\text { FTIR } \\
\text {-Lignin removal } \\
-\mathrm{SO}_{4} \text { group for CNC } \\
\text { Native pop. } 56.1 \% \\
\text { CNC pop. } 72.9 \% \\
\text { CNF pop. } 56.4 \%\end{array}$ & [49] \\
\hline $\begin{array}{l}\text { Poplar Catkin } \\
\text { Fiber }\end{array}$ & $\begin{array}{l}1 \% \mathrm{NaClO}_{2} \text { at } \\
\quad 75^{\circ} \mathrm{C} 1 \mathrm{~h} \\
\text { (repeat } 3 \text { times) }\end{array}$ & $\begin{array}{c}2 \mathrm{wt} \% \mathrm{NaOH} \\
\text { then } \\
5 \mathrm{wt} \% \mathrm{NaOH} \\
\text { at } 90{ }^{\circ} \mathrm{C}\end{array}$ & $\begin{array}{c}\text { Probe sonicator } \\
1 \% \mathrm{wt} \text { soln } \\
600 \mathrm{w} \\
19.5-20.5 \mathrm{kHz} \\
\text { For } 5-10 \mathrm{~min}\end{array}$ & $\begin{array}{c}\text { CNF } \\
15-70 \mathrm{~nm} \\
5 \mathrm{~min} \text { more } \\
\text { sonication } \\
\text { decrease size by } \\
5 \mathrm{~nm}\end{array}$ & $\begin{array}{c}\text { FTIR } \\
\text { Lignin removal }\end{array}$ & [50] \\
\hline $\begin{array}{c}\text { Poplar } \\
\text { (this study) }\end{array}$ & $\begin{array}{c}10 \% \text { wt. } \mathrm{NaOH} \\
120^{\circ} \mathrm{C}, 2 \mathrm{~h}\end{array}$ & $\begin{array}{l}\mathrm{NaClO}_{2} 100{ }^{\circ} \mathrm{C}, \\
\text { acidic medium. } \\
\quad(3-4 \text { times })\end{array}$ & $\begin{array}{c}60 \% \mathrm{H}_{2} \mathrm{SO}_{4}, 40{ }^{\circ} \mathrm{C} \\
\text { for } 5,10 \text {, and } 15\end{array}$ & $\begin{array}{l}\text { CNC } \\
69 \mathrm{~nm}\end{array}$ & $\begin{array}{c}\text { FTIRLignin removal } \\
\text { Crystallinity } \\
\text { Native } 58 \% \\
\text { CNC } 65 \%\end{array}$ & 一 \\
\hline $\begin{array}{c}\text { Alkaline } \\
\text { Peroxide } \\
\text { Mechanical } \\
\text { Pulp (APMP) }\end{array}$ & $\begin{array}{l}\mathrm{NaClO}_{2} \text { at } \\
75^{\circ} \mathrm{C} 1 \mathrm{~h} \\
\text { (twice) }\end{array}$ & $\begin{array}{c}4 \mathrm{wt} \% \mathrm{NaOH} \text { at } \\
80^{\circ} \mathrm{C} \text { for } 2 \mathrm{~h}\end{array}$ & $\begin{array}{l}\text { Probe sonication } \\
15 \text { min } 900 \text { watt }\end{array}$ & $\begin{array}{c}\text { CNF } \\
20-90 \mathrm{~nm}\end{array}$ & $\begin{array}{c}\text { FTIR } \\
\text { Lignin removal } \\
\text { Crystallinity } \\
\text { APMP 72.6\% } \\
\text { CNF 77\% }\end{array}$ & [51] \\
\hline
\end{tabular}


To sum up the comparison in Table 2, we found that enzymolysis was insufficient to yield miniature fiber $(310 \mathrm{~nm})$, even after being aided by $20 \mathrm{~min}$ probe sonication. Disk milling is a reliable alternative; however its high cost inhibits upscaling. Sulfuric acid hydrolysis might be a low-cost good efficiency alternative that can be deployed easily, especially in high crystallinity applications. We should also point out to that CNC costs less than half CNF [52], which promotes CNC compared to CNF.

Results depicted in this article promote poplar as a precursor for nanocellulose, which underwent preliminary experiments to reinforce composites.

\section{Conclusions}

The explained preparation and processing for poplar successfully yielded cellulose nanocrystals $(\mathrm{CNC})$. As the hydrolysis time increases, the dimensions of the resulting crystal decreases, and aspect ratio increases. MCC was more compliant to hydrolysis than poplar wastes, allegedly because lignin and hemicellulose remnants are present even after bleaching. Poplar based nanocellulose was sized 219 length and $69 \mathrm{~nm}$ width after $15 \mathrm{~min}$. MCC yielded 122 length and $12 \mathrm{~nm}$ width crystals after $10 \mathrm{~min}$. The refinement of nanocellulose whiskers versus time can be interpreted by further dissolution of larger rods of nanocellulose yielding finer whiskers.

IR showcased minimal difference between untreated and treated fibers. Acidic hydrolysis resulted in considerable change in more intense peaks at 3500 and $2900 \mathrm{~cm}^{-1}$ for nanocellulose, interpreted by larger specific area and hence higher number of chemical bonds.

Despite the fact that fiber treatments did not significantly impact the crystallinity of poplar, acidic hydrolysis remarkably boosted up crystallinity (CI) by $7-8 \%$. All nanocellulose extracted in this work was mainly cellulose II. The crystalinity increase is attributed to further targeting of acid to amourphus regions.

Nanocellulose sourced from poplar was isolated as planned. However, for future research, it seems that longer duration of pulping and bleaching could have removed unwanted components (hemicellulose and lignin) that showed up in IR and XRD. Moreover, the nanocellulose extracted can be used as reinforcement in biobased composites, especially with regenerated cellulose membranes.

Author Contributions: S.M. Conceptualization, investigation, and writing; E.E.A.-E.M. Interpretation; J.N. Conceptualization; S.S. Investigation; R.G.-S.-M. Investigation and Reviewing. All authors have read and agreed to the published version of the manuscript.

Funding: This research was funded by European Union under umbrella of Erasmus+ KA107 PhD Mobility scheme.

Institutional Review Board Statement: This study involved neither humans nor animals. We were fully compliant to safety instructions in University of Granada during experimentation.

Informed Consent Statement: Not applicable.

Acknowledgments: This paper and the research behind it would have been impossible to deliver, without the financial support from European Union under umbrella of Erasmus+ KA107 Mobility scheme, and purchasing fund from Dept. of Inorganic Chemistry (University of Granada). Furthermore, I would like to appreciate Dept. Chair in Granada Jose Maria Moreno and his kind secretary Antonio de la Torre.

Conflicts of Interest: Authors of this article declare no conflict of interest regarding the submission of this manuscript.

\section{References}

1. Mehanny, S.; Ibrahim, H.; Darwish, L.; Farag, M.; El-Habbak, A.-H.M.; El-Kashif, E. Effect of Environmental Conditions on Date Palm Fiber Composites. In Date Palm Fiber Composites; Springer: Singapore, 2020; pp. 287-320.

2. Kumar, R.; Singh, S.; Singh, O.V. Bioconversion of lignocellulosic biomass: Biochemical and molecular perspectives. J. Ind. Microbiol. Biotechnol. 2008, 35, 377-391. [CrossRef] 
3. Mehanny, S.; Darwish, L.; Ibrahim, H.; El-Wakad, M.T.; Farag, M. High-content lignocellulosic fibers reinforcing starch-based biodegradable composites: Properties and applications. In Composites from Renewable and Sustainable Materials; InTech: Rijeka, Croatia, 2016.

4. Kumar, P.; Barrett, D.M.; Delwiche, M.J.; Stroeve, P. Methods for pretreatment of lignocellulosic biomass for efficient hydrolysis and biofuel production. Ind. Eng. Chem. Res. 2009, 48, 3713-3729. [CrossRef]

5. Ibrahim, M.M.; Moustafa, H.; Rahman, E.N.A.E.L.; Mehanny, S.; Hemida, M.H.; El-Kashif, E. Reinforcement of starch based biodegradable composite using Nile rose residues. J. Mater. Res. Technol. 2020, 9, 6160-6171. [CrossRef]

6. Mehanny, S.; Farag, M.; Rashad, R.M.; Elsayed, H. Fabrication and Characterization of Starch Based Bagasse Fiber Composite. In Proceedings of the ASME International Mechanical Engineering Congress and Exposition, Houston, TX, USA, 9-15 November 2012; p. 1345.

7. Ibrahim, H.; Mehanny, S.; Darwish, L.; Farag, M. A comparative study on the mechanical and biodegradation characteristics of starch-based composites reinforced with different lignocellulosic fibers. J. Polym. Environ. 2018, 26, 2434-2447. [CrossRef]

8. Su, T.; Zhao, D.; Khodadadi, M.; Len, C. Lignocellulosic biomass for bioethanol: Recent advances, technology trends and barriers to industrial development. Curr. Opin. Green Sustain. Chem. 2020, 24, 56-60. [CrossRef]

9. Roman, K.; Barwicki, J.; Hryniewicz, M.; Szadkowska, D.; Szadkowski, J. Production of Electricity and Heat from Biomass Wastes Using a Converted Aircraft Turbine AI-20. Processes 2021, 9, 364. [CrossRef]

10. Hannon, M.; Gimpel, J.; Tran, M.; Rasala, B.; Mayfield, S. Biofuels from algae: Challenges and potential. Biofuels 2010, 1, 763-784. [CrossRef] [PubMed]

11. Qian, X. Statistical Analysis and Evaluation of the Advanced Biomass and Natural Gas Co-Combustion Performance. Ph.D. Thesis, Morgan State University, Baltimore, MD, USA, 2019.

12. Satyanarayana, K.G.; Arizaga, G.G.C.; Wypych, F. Biodegradable composites based on lignocellulosic fibers-An overview. Prog. Polym. Sci. 2009, 34, 982-1021. [CrossRef]

13. Bajpai, P. Structure of lignocellulosic biomass. In Pretreatment of Lignocellulosic Biomass for Biofuel Production; Springer: Cham, Switzerland, 2016; pp. 7-12.

14. Feng, Z.; Shang, B.; Gao, F.; Calatayud, V. Current ambient and elevated ozone effects on poplar: A global meta-analysis and response relationships. Sci. Total Environ. 2019, 654, 832-840. [CrossRef] [PubMed]

15. International Poplar Commission. Food and Agriculture Organization of the United Nations. In Proceedings of the 23rd session of the International Poplar Commission and 44th session of Its Executive Committee, 26-30 October 2008; Beijing, China.

16. Qian, X.; Yang, Y.; Lee, S.W. Design and Evaluation of the Lab-Scale Shell and Tube Heat Exchanger (STHE) for Poultry Litter to Energy Production. Processes 2020, 8, 500. [CrossRef]

17. Christersson, L. Poplar plantations for paper and energy in the south of Sweden. Biomass Bioenergy 2008, 32, 997-1000. [CrossRef]

18. Bacenetti, J.; Gonzalez Garcia, S.; Mena, A.; Fiala, M. Life cycle assessment: An application to poplar for energy cultivated in Italy. J. Agric. Eng. 2012, 72-78. [CrossRef]

19. Dieter, M. Poplars and other fast growing trees-renewable resources for future green economies. In Proceedings of the 25th Session of the International Poplar Commission, Berlin, Germany, 12-16 September 2016. Working Paper IPC/15.

20. Rosúa, J.M.; Pasadas, M. Biomass potential in Andalusia, from grapevines, olives, fruit trees and poplar, for providing heating in homes. Renew. Sustain. Energy Rev. 2012, 16, 4190-4195. [CrossRef]

21. Dufresne, A. Cellulose nanomaterial reinforced polymer nanocomposites. Curr. Opin. Colloid Interface Sci. 2017, 29, 1-8. [CrossRef]

22. Sheltami, R.M.; Kargarzadeh, H.; Abdullah, I.; Ahmad, I. Thermal properties of cellulose nanocomposites. Handb. Nanocellul. Cellul. Nanocompos. 2017, 2, 523-552.

23. Österberg, M.; Vartiainen, J.; Lucenius, J.; Hippi, U.; Seppälä, J.; Serimaa, R.; Laine, J. A fast method to produce strong NFC films as a platform for barrier and functional materials. ACS Appl. Mater. Interfaces 2013, 5, 4640-4647. [CrossRef] [PubMed]

24. Camarero-Espinosa, S.; Endes, C.; Mueller, S.; Petri-Fink, A.; Rothen-Rutishauser, B.; Weder, C.; Clift, M.J.D.; Foster, E.J. Elucidating the potential biological impact of cellulose nanocrystals. Fibers 2016, 4, 21. [CrossRef]

25. Favier, V.; Canova, G.R.; Cavaillé, J.Y.; Chanzy, H.; Dufresne, A.; Gauthier, C. Nanocomposite materials from latex and cellulose whiskers. Polym. Adv. Technol. 1995, 6, 351-355. [CrossRef]

26. Desmaisons, J.; Gustafsson, E.; Dufresne, A.; Bras, J. Hybrid nanopaper of cellulose nanofibrils and PET microfibers with high tear and crumpling resistance. Cellulose 2018, 25, 7127-7142. [CrossRef]

27. Hubbe, M.A.; Ferrer, A.; Tyagi, P.; Yin, Y.; Salas, C.; Pal, L.; Rojas, O.J. Nanocellulose in thin films, coatings, and plies for packaging applications: A review. BioResources 2017, 12, 2143-2233. [CrossRef]

28. Dufresne, A. Nanocellulose processing properties and potential applications. Curr. For. Rep. 2019, 5, 76-89. [CrossRef]

29. Mehanny, S.; Abu-El Magd, E.E.; Ibrahim, M.; Farag, M.; Gil-San-Millan, R.; Navarro, J.; El-Kashif, E. Extraction and characterization of nanocellulose from three types of palm residues. J. Mater. Res. Technol. 2021, 10, 526-537. [CrossRef]

30. Habibi, Y.; Chanzy, H.; Vignon, M.R. TEMPO-mediated surface oxidation of cellulose whiskers. Cellulose 2006, 13, 679-687. [CrossRef]

31. Dufresne, A. Nanocellulose: From Nature to High Performance Tailored Materials; Walter de Gruyter GmbH \& Co KG: Berlin, Germany, 2017.

32. Thomas, B.; Raj, M.C.; Joy, J.; Moores, A.; Drisko, G.L.; Sanchez, C. Nanocellulose, a versatile green platform: From biosources to materials and their applications. Chem. Rev. 2018, 118, 11575-11625. [CrossRef] 
33. Xiao, Y.T.; Chin, W.L.; Abd Hamid, S.B. Facile preparation of highly crystalline nanocellulose by using ionic liquid. Adv. Mater. Res. 2015, 1087, 106-110. [CrossRef]

34. Jiang, F.; Hsieh, Y.-L. Chemically and mechanically isolated nanocellulose and their self-assembled structures. Carbohydr. Polym. 2013, 95, 32-40. [CrossRef] [PubMed]

35. Mandal, A.; Chakrabarty, D. Isolation of nanocellulose from waste sugarcane bagasse (SCB) and its characterization. Carbohydr. Polym. 2011, 86, 1291-1299. [CrossRef]

36. Fahma, F.; Iwamoto, S.; Hori, N.; Iwata, T.; Takemura, A. Isolation, preparation, and characterization of nanofibers from oil palm empty-fruit-bunch (OPEFB). Cellulose 2010, 17, 977-985. [CrossRef]

37. Yang, H.; Yan, R.; Chen, H.; Lee, D.H.; Zheng, C. Characteristics of hemicellulose, cellulose and lignin pyrolysis. Fuel 2007, 86, 1781-1788. [CrossRef]

38. Alvarez, V.A.; Vázquez, A. Influence of fiber chemical modification procedure on the mechanical properties and water absorption of MaterBi-Y/sisal fiber composites. Compos. Part A Appl. Sci. Manuf. 2006, 37, 1672-1680. [CrossRef]

39. Oh, S.Y.; Yoo, D., II; Shin, Y.; Seo, G. FTIR analysis of cellulose treated with sodium hydroxide and carbon dioxide. Carbohydr. Res. 2005, 340, 417-428. [CrossRef] [PubMed]

40. Nelson, M.L.; O'Connor, R.T. Relation of certain infrared bands to cellulose crystallinity and crystal lattice type. Part II. A new infrared ratio for estimation of crystallinity in celluloses I and II. J. Appl. Polym. Sci. 1964, 8, 1325-1341. [CrossRef]

41. Ilyas, R.A.; Sapuan, S.M.; Ishak, M.R. Isolation and characterization of nanocrystalline cellulose from sugar palm fibres (Arenga Pinnata). Carbohydr. Polym. 2018, 181, 1038-1051. [CrossRef]

42. Mora, J.I. Extraction of cellulose and preparation of nanocellulose from sisal fibers. Cellulose 2008, 149-159. [CrossRef]

43. Shi, J.; Shi, S.Q.; Barnes, H.M.; Pittman, C.U., Jr. A chemical process for preparing cellulosic fibers hierarchically from kenaf bast fibers. BioResources 2011, 6, 879-890. [CrossRef]

44. Park, S.; Baker, J.O.; Himmel, M.E.; Parilla, P.A.; Johnson, D.K. Cellulose crystallinity index: Measurement techniques and their impact on interpreting cellulase performance. Biotechnol. Biofuels 2010, 3, 10. [CrossRef]

45. Phanthong, P.; Ma, Y.; Guan, G.; Abudula, A. Extraction of nanocellulose from raw apple stem. J. Jpn. Inst. Energy 2015, 94, 787-793. [CrossRef]

46. Lani, N.S.; Ngadi, N.; Johari, A.; Jusoh, M. Isolation, characterization, and application of nanocellulose from oil palm empty fruit bunch fiber as nanocomposites. J. Nanomater. 2014, 2014, 13. [CrossRef]

47. Qi, Y.; Zhang, H.; Xu, D.; He, Z.; Pan, X.; Gui, S.; Dai, X.; Fan, J.; Dong, X.; Li, Y. Screening of Nanocellulose from Different Biomass Resources and Its Integration for Hydrophobic Transparent Nanopaper. Molecules 2020, 25, 227. [CrossRef] [PubMed]

48. Zhang, Y.; Chen, J.; Zhang, L.; Zhan, P.; Liu, N.; Wu, Z. Preparation of nanocellulose from steam exploded poplar wood by enzymolysis assisted sonication. Mater. Res. Express 2020, 7, 35010. [CrossRef]

49. Zhao, G.; Du, J.; Chen, W.; Pan, M.; Chen, D. Preparation and thermostability of cellulose nanocrystals and nanofibrils from two sources of biomass: Rice straw and poplar wood. Cellulose 2019, 26, 8625-8643. [CrossRef]

50. Wu, Y.; Sun, M.; Wu, X.; Shi, T.; Chen, H.; Wang, H. Preparation of nanocellulose aerogel from the poplar (Populus tomentosa) catkin fiber. Forests 2019, 10, 749. [CrossRef]

51. Li, W.; Zhao, X.; Liu, S. Preparation of entangled nanocellulose fibers from APMP and its magnetic functional property as matrix. Carbohydr. Polym. 2013, 94, 278-285. [CrossRef] [PubMed]

52. Nelson, K.; Retsina, T.; Iakovlev, M.; van Heiningen, A.; Deng, Y.; Shatkin, J.A.; Mulyadi, A. American process: Production of low cost nanocellulose for renewable, advanced materials applications. In Materials Research for Manufacturing; Springer: Cham, Switzerland, 2016; pp. 267-302. 